\title{
Water resources management: traditional technology and communities as part of the solution
}

\author{
J. HUSSAIN ${ }^{1}$, I. HUSAIN ${ }^{2}$ \& M. ARIF ${ }^{3}$ \\ 1 Central Groundwater Board, North Western Region, Ministry of Water Resources, Chandigarh, India \\ drjakirhussain@gmail.com \\ 2 Public Health Engineering Department Laboratory, Bhilwara, Rajasthan \\ 3 Department of Chemistry, Banasthali University, Tonk, India
}

\begin{abstract}
Rajasthan, the largest State in India, has one of the most critical water statuses. Rajasthan, with more than $10.4 \%$ of the country's geographical area, supports more than $5.5 \%$ of the human population and $18.70 \%$ of the livestock, but only has $1.16 \%$ of the total surface water available in the country. More than $60 \%$ of the state is a part of the Great Thar Desert, and of the total 142 desert blocks in the country, 85 blocks are in the state of Rajasthan. The per capita annual water availability in the state is about $780 \mathrm{~m}^{3}$, compared with the minimum requirement of $1000 \mathrm{~m}^{3}$. It is feared that the availability would fall below $450 \mathrm{~m}^{3}$ by the year 2050 . Thus, increasing population coupled with erratic rainfall further aggravates the water crisis. It is possible to harvest and augment water resources through the construction of small water harvesting structures called johads and the implementation of local water governance. This has been amply demonstrated by the successful experience of local communities in Alwar District in Rajasthan. Since 1985, 8600 johads have been built in 1086 villages. This has resulted in the rise in water levels in the shallow aquifer, increase in the area under single and double crops, increase in forest cover and drinking water supply security. The water collected in a johad during the monsoon penetrates into the sub-soil. This recharges the groundwater and improves the soil moisture in vast areas. The water in the johad can be used directly for irrigation, drinking water by animals, and other domestic purposes. The other advantage of this structure is that it checks soil erosion, mitigates floods, and ensures water availability in wells or boreholes used for drinking water supply, even for several successive drought years. Also, during the dry season when the water gradually recedes in the johad, the land inside the johad itself becomes available for cultivation.
\end{abstract}

Key words Thar Desert; groundwater; traditional water harvesting; johad; Rajasthan, India

\section{INTRODUCTION}

Water is the most essential natural resource for life. It is likely to become a critical scarce resource in many regions of the world in the coming decades (NIOS 2012). Although water is the most abundant substance on Earth, it is not equally distributed. Variations in latitude, rainfall patterns, topography, and additional hydrological and geomorphological factors affect its availability. The total fresh and sea water content of the Earth is fixed. The freshwater which is essential for human life, is only a small portion of the total water available on this Earth - about $2.7 \%$. Although India is one of the wettest countries in the world (i.e. it receives about $1150 \mathrm{~mm}$ of rainfall annually), the spatio-temporal water availability is highly uneven. For example, the average number of rainy days in a year is only 40 . Thus there is a long dry period in a year. Also, rainfall spatial distribution ranges from $13 \mathrm{~m}$ in some areas of northeast regions to $12 \mathrm{~cm}$ in certain parts of Rajasthan. Therefore, this uneven distribution of rainfall results in severe water scarcity in many parts of the country.

With increasing demand for domestic, industrial and agriculture purposes the water availability is decreasing and it is likely that this situation is going to get worse in the future. Moreover, during the past few decades efforts have been made to increase irrigation in the country. This has resulted in over-exploitation of the country's water resources. Increasing urbanization and industrialization has also made additional demands for water. All the above factors contribute to severe water scarcity in some parts.

Just as the 20th century focused on the importance of oil, the 21 st century is likely to focus on issues concerning safe and adequate drinking water (NIOS 2012). The most important step in the direction of finding solutions to issues of water and environmental conservation is to change people's attitudes and habits. If the world continues to treat water as a cheap resource that can be wasted, then not even the best policies and technologies can help to solve water scarcity.

Efforts are required to retain more and more rain water for use during the dry period. Rainwater harvesting at local level by either storing in ponds, tanks and lakes or by recharging 
groundwater are simple methods of augmenting water supply. In the following sections some important methods of rainwater harvesting are described.

\section{RAJASTHAN}

Rajasthan State, formerly known as Rajputana, came into existence on 30 March 1949. It occupies $342239 \mathrm{~km}^{2}$ area covering $10.74 \%$ of the Indian territory and is the largest State in India. The State is located within $23^{\circ} 03^{\prime}-30^{\circ} 12^{\prime} \mathrm{N}$ and $69^{\circ} 9^{\prime}-78^{\circ} 17^{\prime} \mathrm{E}$ and bounded on the west and northwest by Pakistan, on the north and northeast by Haryana and Uttar Pradesh, and on the southeast and southwest by Madhya Pradesh and Gujarat states, respectively. The northwestern part of the State is occupied by the Thar Desert, covering 32\% area of the total area. The Aravalli Hill range extending from Delhi in the northeast to the plains of north Gujarat in the southwest, divides the state into two unequal parts. The area to the east of the hills is covered by the eastern plains and the Vindhyan plateau (Geological Survey of India 2011).

Thar Desert is described as one of the most inhospitable regions of the world, and is almost a rainless desert. Some areas do not receive more than $120 \mathrm{~mm}$ of annual rainfall. Yet this desert is the most densely populated desert in the world. It has been continuously habited for over 1200 years. The people of this region made sagacious use of natural resources, particularly water to sustain human and livestock populations (CGWB 2011).

\section{Groundwater resources}

The estimated groundwater resources in Rajasthan are limited due to deep aquifers and low recharge. The groundwater is overexploited in Ajmer, Alwar, Barmer, Bhilwara, Chittorgarh, Dausa, Dholpur, Jaipur, Jalore, Jhunjhunu, Jodhpur, Nagaur, Sikar and Udaipur districts, and, on average, over the entire state (CGWA 1999). In the last 10 years, of the total 236 blocks (administrative zones) in the state, the number of safe blocks decreased from 155 to 49 . The impact of droughts on groundwater depletion was very spectacular in the hard rock regions of Udaipur, Rajsamand, Dungarpur, Bhilwara, Chittorgarh, Ajmer, Sirohi and Pali districts, which have a limited aquifer thickness. In these districts, nearly 60 blocks have moved in to the semicritical, critical and overexploited stages (Narain et al. 2005).

\section{WATER HARVESTING AND ITS POTENTIAL FOR DROUGHT MITIGATION}

Water harvesting and conservation at different spatial scales (from catchment, field or micro level) can bring sustainability to the water sector and, consequently, increase water availability in drought years. Water harvesting is the process of concentrating rainfall as runoff from a catchment to be used in a target area. In Rajasthan, and particularly in the low-rainfall western zone, there are several kinds of rainwater harvesting systems such as bawari, jhalara, talab, nadi, tanka, khadin, kund and harvesting of roof water. Out of these, bawari and jhalara depend on groundwater, while talab, nadi, tanka, johad, kund and khadin are based on harnessing surface runoff (Khan 1995, Khan and Narain 2000). With the implementation of government schemes for domestic water supply in many areas, some of these systems were neglected. However, with increasing human population, shortfall in groundwater and recurring droughts, these rainwater harvesting systems are attracting growing attention. Modern technologies of rainwater harvesting and groundwater recharge such as anicut, percolation tank, subsurface barrier and pond with infiltration wells, have recently been developed to rejuvenate the depleted freshwater aquifers (Khan 1996a,b, Narain and Khan 2000, 2002).

\section{Traditional methods of water harvesting in Rajasthan}

Kund or kundi look like an upturned cup nestling in a saucer (Fig. 1(a)). These structures harvest rainwater for drinking, and dot the sandier tracts of the Thar Desert in western Rajasthan and some areas in Gujarat. Essentially, a circular underground well, kunds have a saucer-shaped catchment area (called Agor) that gently slopes towards the centre where the well is situated. A 

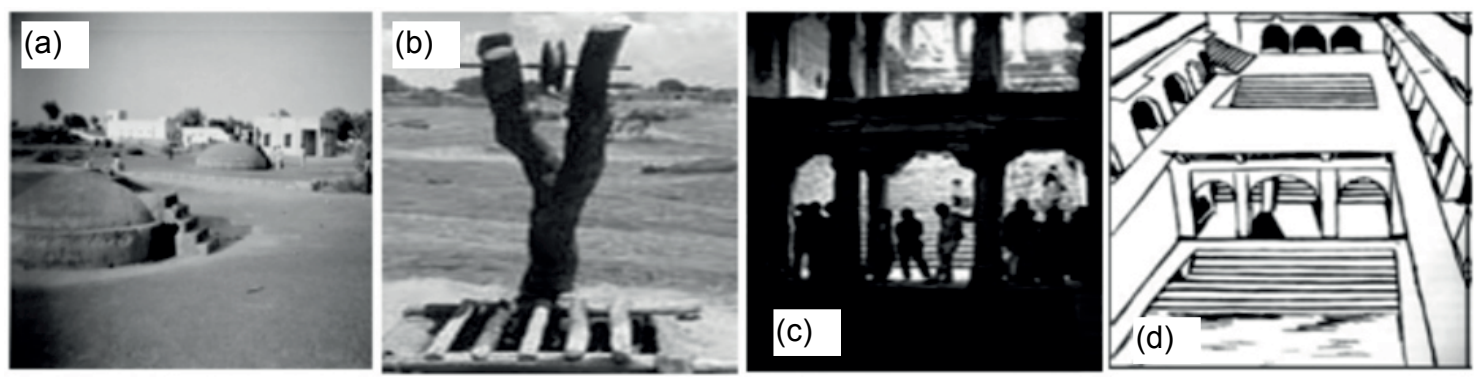

Fig. 1 (a) Kund/Kundi, (b) Kuis/Beris, (c) Baoris/Bers, (d) Jhalara.
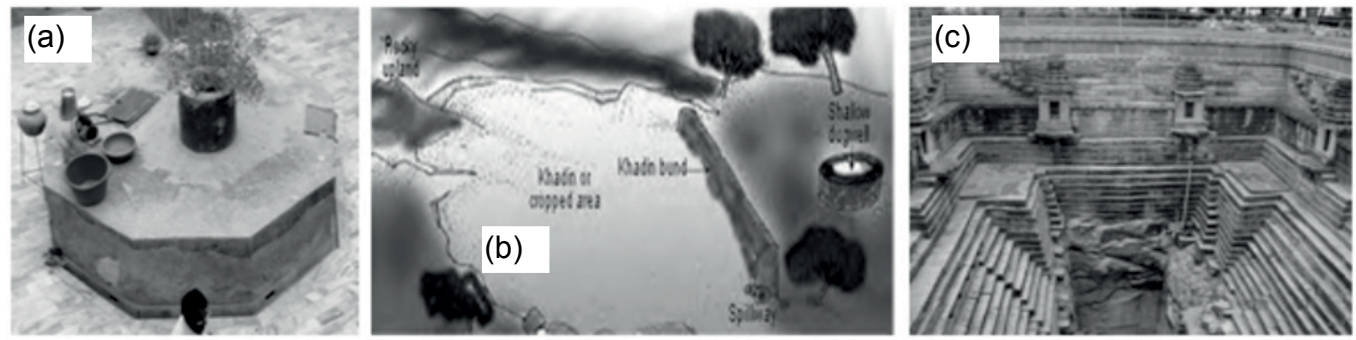

Fig. 2 (a) Tanka, (b) Khadin, (c) Bavadi/Vav/Vavdi/Baoli.

wire mesh across water-inlets prevents debris from falling into the well-pit. The sides of the wellpit are covered with (disinfectant) lime and ash. Most pits have a dome-shaped cover, or at least a lid, to protect the water. If needed, water can be drawn out with a bucket. The depth and diameter of kunds depend on their use (drinking, or domestic water requirements). These are owned by people with money to invest and land in which to construct them. For the poor, large public kunds were built (CGWB 2011).

Kuis / Beris are found in western Rajasthan, these are 10- to 12-m-deep pits dug near tanks to collect the seepage. Kuis can also be used to harvest rainwater in areas with meagre rainfall (Fig. 1(b)). The mouth of the pit is usually made very narrow. This prevents evaporation of the collected water. The pit gets wider as it burrows under the ground, so that water can seep in into a large surface area. The openings of these entirely kuchcha (earthen) structures are generally covered with planks of wood, or put under lock and key. The water is used sparingly as a last resort in crisis situations (CGWB 2011).

Baoris / Bers are community wells, found in Rajasthan, that are used mainly for drinking purposes. Most of them are very old and were built by banjara (mobile trading communities) for their drinking water needs. They can hold water for a long time because of almost negligible water evaporation (Fig. 1(c)).

Jhalara is a local name given to step wells. Jhalaras were hriman-made tanks, found in Rajasthan and Gujarat, essentially meant for community use (a) for religious rites. Often rectangular in design, jhalaras have steps on three or four sides (Fig. 1(d)). Jhalars are groundwater bodies which are built to ensure easy and regular supply of water to the surrounding areas. The jhalaras collect subterranean seepage of a talab or lake located upstream. The water from these jhalaras was not used for drinking, but only for community bathing and religious rites. Jhodhpur city has eight jhalaras, two of which are inside the town and six are found outside the city. The oldest jhalara is the Mahamandir Jhalara, which dates back to 1660 AD (CGWB 2011).

A Nadi or dug-out village pond is the oldest and still the most prevalent storage structure for rainwater harvesting from an adjoining natural catchment during the rainy season. The site was selected by the villagers based on available natural catchments and its water yield potential. The water stored in a nadi is generally used for drinking by livestock and human beings. A nadi also acts as a source of groundwater recharge through seepage and deep percolation. It is estimated that 
the recharge from a nadi covering 2.25 ha and having a storage capacity of $15000 \mathrm{~m}^{3}$ in an alluvial area may induce a groundwater recharge of $10000 \mathrm{~m}^{3}$ in one rainy season. The location of the nadi had a strong bearing on its storage capacity due to the related catchment and runoff characteristics (CGWB 2011).

The Tanka (underground cistern) is another major source of drinking water in western Rajasthan (Husain and Husain 2012). It is constructed in a circular or rectangular shape, normally on bare ground where surface runoff can be diverted to the tanka by creating a clean catchment around it (Fig 2(a)). A traditional tanka constructed with lime plaster and thatched with bushes has a life span of 3-4 years. In this way, the people of Bikaner were able to meet their water requirements (CGWB 2011).

Khadin, also called adhora, is an ingenious construction designed to harvest surface runoff water for agriculture (Fig. 2(b)). Its main feature is a very long (100-300 m) earthen embankment built across the lower hill slopes lying below gravelly uplands. Sluices and spillways allow excess water to drain off. The khadin system is based on the principle of harvesting rainwater on farm land and subsequent use of this water-saturated land for crop production. First designed by the Paliwal Brahmins of Jaisalmer, western Rajasthan in the 15th century, this system has great similarity with the irrigation methods of the people of Ur (present Iraq) around $4500 \mathrm{BC}$ and later of the Nabateans in the Middle East (CGWB 2011).

Vav / Vavdi / Baoli / Bavadi, Traditional stepwells are called vav or vavadi in Gujarat, or baolis or bavadis in Rajasthan and northern India. Built by the nobility usually for strategic and/or philanthropic reasons, they were secular structures from which everyone could draw water (Fig. 2(c)). Most of them are defunct today. Step well locations often suggested the way in which they would be used. When a step well was located within or at the edge of a village, it was mainly used for utilitarian purposes and as a cool place for social gatherings. When step wells were located outside the village, on trade routes, they were often frequented as resting places. When stepwells were used exclusively for irrigation, a sluice was constructed at the rim to receive the lifted water and lead it to a trough or pond, from where it ran through a drainage system and was channelled into the fields (CGWB 2011).

Naada / bandha is found in the Mewar region of the Thar Desert. It is a stone check dam, constructed across a stream or gully, to capture monsoon runoffon a stretch of land. Submerged in water, the land becomes fertile as silt deposits on it and the soil retains substantial amounts of water (CGWB 2011).

\section{JOHAD: A TRADITIONAL WATER HARVESTING SYSTEM}

A johad is a traditional water harvesting structure. Johads are small earthen check dams that capture and conserve rainwater, improving percolation and groundwater recharge, constructed by people using their own skills, resources and indigenous knowledge; these have revolutionized life in rural Alwar, Rajasthan. These have helped the farming communities from abject poverty to prosperity, a miraculous transformation under the leadership of Tarun Bharat Sangh and its leader Rajendra Singh, the Water Man of Rajasthan (Frontline 2001).

The johads are simple, usually semi-circular, mud barriers built across the hill slopes to arrest the monsoon runoff. They are built across a slope to arrest rainwater; bound on three sides by the natural slopes of hills. The fourth side, a mud wall usually semi-circular in form holds back the monsoon runoff (Fig. 3). The height of the embankment varies from one johad to another, depending on the site, water flow, contours, etc. In some cases, to ease the water pressure, a masonry structure is also added for the outlet of excess water (Sharma 2006). The water storage area varies from 2 ha to 100 ha. The optimal storage created was $1000-1500 \mathrm{~m}^{3}$ per hectare of cultivated area. The cost of the storage created varied from Indian Rupee (Rs) 0.2 to Rs. $1.50 / \mathrm{m}^{3}$, with an average of Rs. $0.95 / \mathrm{m}^{3}$. The villagers shared the cost, supplied labour and materials like stone, sand and lime, which were locally available and contributed $70-90 \%$ of the total cost. The distinctiveness of these structures lay in their low cost, simple design, easy construction and 


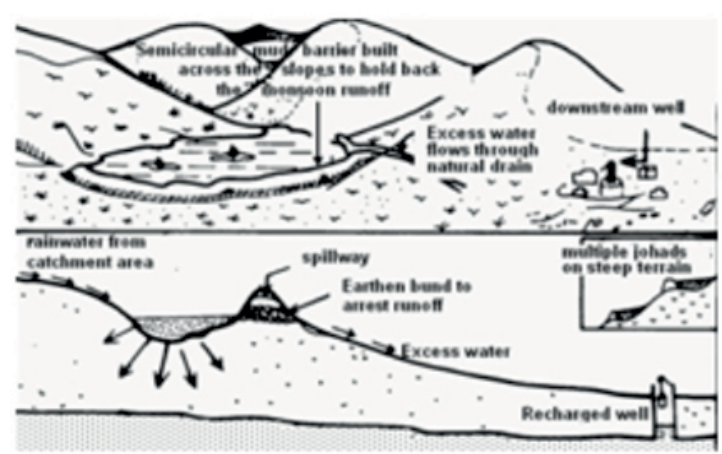

Fig. 3 Rainwater harvesting using johads (adapted from Kishore 2003).

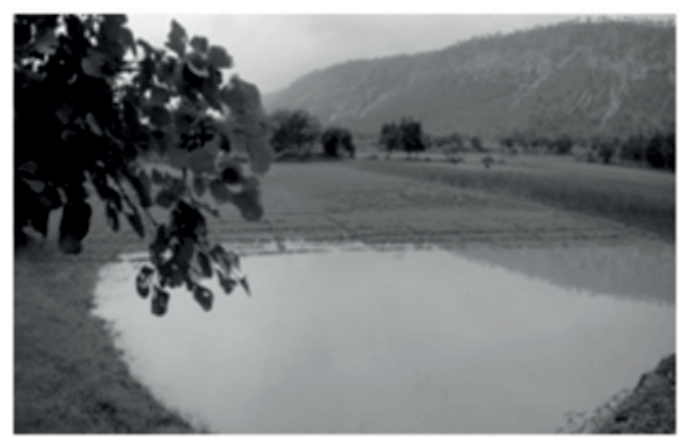

Fig. 4 Rainwater harvesting structure johads.

maintenance. These indigenously designed structures stood the test of time and the ravages of heavy rainfall (Das 2010). The water collected in a johad during the monsoon is directly used for irrigation, drinking, livestock and other domestic purposes, and penetrates into the sub-soil. This recharges the groundwater and improves the soil moisture in vast areas. Also, during the dry season when the water gradually recedes in the johad, the land inside the johad itself becomes available for cultivation.

A total of 8600 johads have been built in 1086 villages of Alwar district covering $6500 \mathrm{~km}^{2}$. This has resulted in the shallow aquifer recharge in groundwater bringing up the water table from about 100-120 m depth to 3-13 $\mathrm{m}$ at present. The area under single cropping and double cropping was $11 \%$ and $3 \%$, which was increased to $70 \%$ and $50 \%$, respectively, resulting in prosperity for the farmers. The forest cover, which used to be around $7 \%$, increased to $40 \%$ through agro-forestry and social forestry, providing sufficient fuel wood and sequestering carbon from the atmosphere. It is estimated that for per capita investment of Rs. 100 on johad, results in Rs. 400 annual profit by increasing crop production. Fisheries also developed, an important source of livelihood. A significant social impact has been emancipation of the status of women in decision making. The most spectacular achievement is the rejuvenation of the Arvari and Ruparel rivers through rainwater harvesting and groundwater recharge (Sharma 2006, Das 2010).

A study conducted by Dr G. D. Agarwal, former head of department of civil engineering at the Indian Institute of Technology, Kanpur (in Kavarana 2006) showed that the structures were extremely cost-effective ranging from a low of Rs. 0.2/ (US cents 0.4) per cubic metre of storage capacity to a high of Rs. 3 (US cents 7) per cubic metre and an average of Rs. 0.95 (US cents 2.2) per cubic metre. In the villages covered by the study, the annual per capita income rose from a low of Rs. 126 (US \$ 2.95) to a high of Rs. 3585 (US \$ 83.98). The study found that an investment of Rs. 1000 on johads raised economic production by over Rs. 4200/annum (Kavarana 2006).

The johad has become a force to mobilize people, optimize social cohesion, promote self reliance and emotive bonding of the community, and activate the community for the common good (Rajendra Singh 2005, Community Driven Decentralised Water Management. Talk in Parliament Forum on Water Conservation and Management, 2005, New Delhi). Aquifers have been recharged Table 1 Rise in groundwater level in Village Buja (Source: AFPRO 1994). 


\begin{tabular}{llll}
\hline $\begin{array}{l}\text { S. } \\
\text { No. }\end{array}$ & $\begin{array}{l}\text { Total depth } \\
\text { of well }\end{array}$ & $\begin{array}{l}\text { Depth of water level } \\
\text { Before constriction of johad (1985) }\end{array}$ & After constriction of johad (1994) \\
\hline 1 & 24.68 & Dry & 11.12 \\
2 & 22.25 & Dry & 10.98 \\
3 & 20.40 & 19.40 & 8.05 \\
4 & 17.00 & 15.7 (mostly dry) & 8.80 \\
5 & 24.68 & 21.68 & 4.57 \\
6 & 21.00 & 15.00 & 5.76 \\
7 & 25.30 & 19.30 & 7.63 \\
8 & 20.25 & Dry & 12.63 \\
\hline
\end{tabular}

and water supply is now ensured for the entire year to meet the needs of both people and livestock. Table 1 presents an example from one of the villages that benefited by constructing johads.

Livestock rearing being the lifeline of local communities, increased water and fodder availability has brought about an improvement in their economic status. Besides satisfying primary needs, drinking and domestic uses, it has increased food production, helped in conserving soil, increased biomass productivity, and even converted five seasonal rivers (Arvari, Ruparel, Sarsa, Bhagani-Teldeh and Jahajwali) into perennials (Sharma 2006).

\section{ROLE OF COMMUNITIES AND INDIVIDUALS}

In those days, centuries ago, the state built only large storage areas, essentially for irrigation and water supply for the capital cities and important towns. These were obviously not enough and, therefore, the village communities and individuals were encouraged to build their own water harvesting devices to meet their basic domestic requirement for water. The communities being closely knit had a strong culture of providing voluntary labour and material contributions for building these facilities for the common good. The social norms for civilized behaviour, inter alia, enjoined on the community members to maintain these facilities, conserve and protect water from pollution and ensure its equitable and fair distribution. Social scientists, historians and scholars have found that there was no problem of water scarcity where the community organizations were strong and the people relied upon their own efforts to build water harvesting structures. However, the situation was bad where the people depended entirely on the state for water.

\section{REFERENCES}

AFPRO (1994) Survey conducted by AFPRO (Agriculture for Food Production) in Village Buja, Alwar District, Rajasthan. Ecologist Asia, 11(3), July-September 2003.

Basic Statistics of Rajasthan (2003) Directorate of Economics and Statistics, Government of Rajasthan. Jaipur, India.

Central Groundwater Authority (CGWA) (1999) Groundwater situation status of development and proposed strategy and policy for management in Rajasthan. Jaipur, India: CGWA. Page no. 22.

Central Groundwater Board (CGWB) (2011) Select case studies rain harvesting and artificial recharge, page no 9-11. Central Groundwater Board, Ministry of Water Resources, New Delhi.

Das, S. (2010) Johads of Alwar. Journal of Geological Society India 75(2), 446-447.

Geological Survey of India (2011) Geology and mineral resources of Rajasthan, Miscellaneous Publication, No. 30 Part 12 • 3rd Revised Edition, page 1-2, Govt. of India.

Frontline (2001) The Water Man of Rajasthan, Volume, 18, Issue, 17, August 18-23 .

Husain, I. and Husain, J. (2012) Traditional \& Successful Practices in Water Scarcity "Thar Desert", Rajasthan, India. World Water Week 2012, SIWI, Stockholm.

Kavarana, G. (2006) The value of a raindrop. Traditional RWH systems, particularly in the arid and semiarid regions of Rajasthan and Gujarat. UNESCO G-WADI meeting on water harvesting Aleppo Syria 20-22, November, 2006 , p. 54.

Khan, M. A. and Narain, P. (2000) Traditional water harvesting systems and their relevance in the present context. In: National Seminar on Groundwater Management Strategies in Arid and Semi Arid Regions. Proceedings. Jaipur, India: Groundwater Department, Government of Rajasthan, pp. 19-27.

Khan, M. A. (1995) Traditional water management systems of western Rajasthan. In. 2nd Congress on Traditional Science and Technology of India. Proceedings. Madras, India: Anna University, p. 220.

Khan, M. A. (1996a) Sustainable development of water resources to augment rural water supply and to improve biomass production in arid ecosystem of Rajasthan. In: III Water Congress, Indian Institute of Technology. Proceedings. New Delhi, India. Page no. 136.

Khan, M. A. (1996b) Inducement of groundwater recharge for sustainable development. In 28th Annual Convention, Indian Water Works Association, Jodhpur, India, pp. 147-150. 
Kishore, A. (2003) Taking control of their lives. Ecologist Asia, 11 (3), July-September.

Narain, P. and Khan, M. A. (2000) Water resources development and utilization for drinking and plant management in Indian arid regions. In: Advances in Land Resources Management for 21st Century. International Conference on Land Resources Management for Food, Employment and Environmental Security. Proceedings. New Delhi, India: Soil Conservation Society of India, pp. 404-414.

Narain, P. and Khan, M. A. (2002) Water for food security in arid zone of India. Indian Farming 52(7), 35-39.

Narain, P., Khan, M. A. and Singh, G. (2005) Potential for water conservation and harvesting against drought in Rajasthan, India. Working Paper 104 (Drought Series: Paper 7) page 6, Colombo, Sri Lanka: International Water Management Institute (IWMI).

National Institute of Open Schooling (NIOS) (2012) Method of Water Harvesting,30, Module 8A, Water Resources Management, http://download.nos.org/333 courseE/30.pdf.

Sharma, A. (2006) Water harvesting context in the Indian Subcontinent, UNESCO G-WADI meeting on water harvesting Aleppo Syria 20-22, November, 2006, pp. 63-70. 